\title{
David in the role of a second Moses - The revelation of the temple-model (tabnit) in 1 Chronicles 28
}

\section{Introduction}

Commentaries on the book of Chronicles emphasize the important role given to David in this book. In 1 Chronicles 10-29 David in fact plays a major role as king of Israel fulfilling various functions such as political governor, military leader and also founder of the temple in Jerusalem and its cult. The last-mentioned role is prominently described in 1 Chronicles 28 . Here David visibly enters into competition with Moses: Like the latter in the Priestly tabernacle account, David receives from YHWH a blueprint (tabnit) of the sanctuary to be built. Furthermore, 1 Chronicles 29 reports how David took the lead in donating to the Temple (vv. 2-5). According to 1 Chronicles 23-26, David also appointed the Levites and organized them into divisions. David's acts are visibly reminiscent of the Priestly tabernacle account and other (late) Priestly texts in the Pentateuch.

The importance given to David as initiator of the cult in Jerusalem deserves all the more attention since the Book of Chronicles refers to the Torah as a binding law several times, identifying it as the Torah of Moses. ${ }^{1}$ About half of all mentions specify Torah as written law. ${ }^{2}$ Among the texts concerned and laws referred to are late Pentateuchal texts, such as Numbers 28:3-8; Exodus 29:38-42 and Deuteron-

\footnotetext{
11 Chron 16:40; 22:12; 2 Chron 6:16; 12:1; 14:3; 15:3; 17:9; 19:10; 23:18; 25:4; 30:16; 31:3, 4; 31:21; 33:8; 34:14, 15, 19; 35:26. The specification “Torah of Moses" is found in 2 Chron 23:18; 30:16; 34:14. For an analysis of these texts, see Lars Maskow, Tora in der Chronik. Studien zur Rezeption des Pentateuchs in den Chronikbüchern, FRLANT 274 (Göttingen: Vandenhoeck \& Ruprecht, 2019). 21 Chron 16:40; 2 Chron 17:9; 23:18; 25:4; 31:3; 34:14, 15, 19; 35:26. As Thomas Willi ("Tora in den biblischen Chronikbüchern,” Judaica 36 [1980): 102-5, 148-51, here 104) has shown, the use of the term Torah is nevertheless broader and includes oral instruction and application of the torâ. Quite illustrative is the statement of 2 Chron 15:3 ("And for many days Israel was without the true God and without a teaching priest and without torâ"). Since the assertion refers to the post-Mosaic era, "torâ" here does not mean the written law but rather the application of the Torah by an authorized priest.
}

Jürg Hutzli, University of Lausanne 
omy 17:14-20. ${ }^{3}$ Therefore, it seems probable that the Chronicler presupposes the Pentateuch, or at least an early stage of it, and that he considers the latter authoritative. ${ }^{4}$ Consequently, regarding the tabnit-motif in 1 Chronicles 28, one has to address the question of its relationship to the tabnit of Moses. More generally, one should ask whether there is a conflict of competence between the two pivotal figures since both of them appear as founders of the Israelite cult. In the context of this question, it is striking that Moses, the lawgiver and "man of God", is only rarely mentioned in Chronicles. He fades compared to David who plays a major role as king of Israel in a large part of the composition (1 Chron 11-29), ${ }^{5}$ and who is also called "man of God."6

The present essay aims first to elucidate the diverse activities of King David related to the foundation of the first temple of Jerusalem and its cult. The second part of the paper will consider the question of how David's striking equation with Moses, Israel's cult founder par excellence, should be understood. Is he a second Moses? What is the status of the instructions compiled by him in comparison with that of the Torah? This question seems to have attracted only little attention in scholarship. ${ }^{7}$ The importance of David in general is often explained with reference to the Chronicler's hope for a restauration of the Davidic monarchy in the late Persian or early Hellenistic era, ${ }^{8}$ or rather as an eschatological messianic expec-

3 The mentioned laws are related to the tamîd-sacrifice and law of the king, which are considered late by an increasing number of scholars. See the respective treatments in Maskow, Tora in der Chronik, 80-81, with n. 78 lit. (tamîd-sacrifice); 96, with n. 128 lit. (law of the king).

4 See Martin Noth, The Chronicler's History, transl. Hugh G. M. Williamson (Sheffield: JSOT Press, 1987), 100; Hans-Peter Mathys, "Die Ketubim," in Die Entstehung des Alten Testaments, ed. Walter Dietrich et al., Theologische Wissenschaft 1 (Stuttgart: Kohlhammer, 2014), 593; Konrad Schmid, Literaturgeschichte des Alten Testaments: Eine Einführung (Darmstadt: Wissenschaftliche Buchgesellschaft, 2008), 147.

5 According to Knoppers's word-count, the David-section covers no less than $27,5 \%$ of the entire book. See Gary N. Knoppers, 1 Chronicles 10-29: A New Translation with Introduction and Commentary, Anchor Bible (New York: Doubleday, 2004), 903.

6 Concerning the attribute "man of God", see below $\S 3$.

7 For short treatments of this question, see Gerhard von Rad, Das Geschichtsbild des chronistischen Werkes (Stuttgart: Kohlhammer, 1930), 130-31, 136; Sara Japhet, The Ideology of the Book of Chronicles and Its Place in Biblical Thought, transl. A. Barber (Frankfurt a/M-Bern-New York: Lang, 1989), 237-38. More elaborate are Simon J. de Vries, "Moses and David as Cult Founders in Chronicles,” JBL 107 (1988): 619-39; Georg Steins, “Chronistisches Geschichtsbild und 'levitische Predigt'. Überlegungen zur Eigenart der Chronik im Anschluss an Gerhard von Rad,” in Das Alte Testament - ein Geschichtsbuch? ed. E. Blum et al., Altes Testament und Moderne 10 (Münster: Litverlag, 2005), 147-73, here 169-70.

8 See Noth, The Chronicler's History, 105-6; Wilhelm Rudolph, "Problems of the Books of Chronicles,” VT 4 (1954): 404-9; André Caquot, “Peut-on-parler de messianisme dans l'oeuvre 
tation. ${ }^{9}$ However, if one or the other were the case, why, one should ask, would the author put such emphasis on David's competence for the conceptualization and the establishment of the Jerusalemite cult. In view of this strong focus, one might imagine another main reason for the great importance assigned to David by the author: it might have less to do with his significance as dynasty founder and bearer of messianic hopes than with the high value given to the Jerusalemite temple and its foundation which necessitated an appropriate founder personality. ${ }^{10}$ David's importance in the Book of Chronicles consists primarily in his role of founder of Israel's unique sanctuary and the organization of its cult.

\section{David as Cult founder in the books of Chronicles}

The following part explores the different functions David fulfills in Chronicles as founder of the temple and its cult. We begin with the motif that David received the divine plan of the temple, the tabnit (cf. 1 Chron 28).

\subsection{David receives from YHWH a plan or blueprint (tabnît) of the future sanctuary (1 Chron 28)}

The Chronicler takes over this motif from the Priestly tabernacle account (Exod 25-40). Therefore, it is useful to bring to mind the concept of the tabnit as it appears in this section. Several statements underline that the tabnit is "shown" to Moses (ראה hi.). ${ }^{11}$ With regard to this verb, most scholars conjecture that Moses is presented with a model; either the three-dimensional celestial proto-type of the

du Chroniste?," RTP 3/16 (1966): 110-120; Rudolf Mosis, Untersuchungen zur Theologie des chronistischen Geschichtswerkes, Freiburger Theologische Studien 92 (Freiburg-Basel-Wien: Herder, 1973), 162-63.

9 See J. Wilhelm Rothstein and Johannes Hänel, Kommentar zum ersten Buch der Chronik, KAT (Leipzig: A. Deicherstsche Verbuchhandlung, 1927), xliii-xliv; Von Rad, Das Geschichtsbild des chronistischen Werkes, 119-32; Walter Brueggemann, David's Truth in Israel's Imagination and Memory, 2nd Edition (Minneapolis: Fortress Press, 2002), 101-2.

10 Similarly Georg Steins, Chronistisches Geschichtsbild und 'levitische Predigt', 159; Pancratius C. Beentjes, Tradition and Transformation in the Book of Chronicles, SSN 52 (Leiden: Brill, 2008), 56.

11 See Exod 25:9, 40; 26:30; 27:8. 
tabernacle (the "tent of YHWH") ${ }^{12}$ or a real miniature model. ${ }^{13}$ The second possibility is supported by the fact that miniature homes and clay model houses have been found throughout the ancient Near East. ${ }^{14}$

What does tabnit in Chronicles mean and how does David gain insight in it? The term tabnit appears in total four times; all occurrences are found in 1 Chronicles 28. Since the texts in question contain certain difficulties, they are shortly discussed:

\subsubsection{Chronicles 28:11}

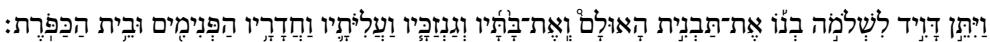
Then David gave to his son Solomon the plan (tabnit) of the porch (of the temple), its buildings, its storehouses, its upper rooms, its inner rooms, and the room for the mercy seat.

Most scholars understand tabnit in the sense of a written document. This understanding is supported by verse 19 (see below) in which a written document is mentioned. If correct, the conception of the tabnit deviates from the "model"-concept of the tabernacle account. In the latter, the tabnit never is associated with a written document. Another difference: David as recipient of the tabnit hands it over to another leading figure, Solomon.

\subsubsection{Chronicles 28:12}

The subsequent verse mentions another plan (tabnit), which David gives to Solomon. Translators and commentators do not agree on the meaning of the expression ברוח in the statement in question. It is rendered either by "in mind" or "by the Spirit (of God)."

12 Umberto Cassuto, A Commentary on the Book of Exodus (Jerusalem: Magnes, 1967), 322; Richard J. Clifford, “The Tent of El and the Israelite Tent of Meeting,” CBQ 33: 221-27, here 226.

13 Victor A. Hurowitz, I Have Built You an Exalted House: Temple Building in the Bible in Light of Mesopotamian and Northwest Semitic Writings, JSOTSup 115 (Sheffield: Sheffield Academic Press, 1992); William H. C. Propp, Exodus 19-40, Anchor Bible (New York: Doubleday, 2006), 376-77.

14 Cf. Propp, Exodus 19-40, 376-77 with reference to Maria G. Masetti-Rouault, "Les maquettes dans les textes mésopotamiens," in 'Maquettes architecturales' de l'Antiquité, ed. B. Muller, Université Strasbourg Travaux du centre de recherche sur le Proche-Orient et la Gréce antiques 17 (Paris: de Boccard, 2001), 445-61. 
and the plan (tabnit) of all that he had (in mind) by the Spirit: of the courts of the House of the LORD and all its surrounding chambers, and of the treasuries of the House of God and of the treasuries of the holy things; (TANAKH, 1985, The Jewish Publication Society). ${ }^{15}$

and the plan (tabnit) of all that he had in mind, for the courts of the house of the LORD, and for all the surrounding rooms, for the storehouses of the house of God, and for the storehouses of the dedicated things; (The New American Standard Bible, 1977) ${ }^{16}$

Which understanding is preferable? Gary N. Knoppers's argument in favor of the understanding "by the Spirit" in his commentary seems pertinent: "Some (...) prefer to translate 'he had in his mind' (...). This is possible, but one wonders why the writer did not write hāyâ 'im lěbābô, as one might expect." ${ }^{17}$ The expression hāyâ 'im lěbābô ("he had in his heart [=his mind]") appears in 1 Chronicles 22:7; 28:2; 2 Chronicles 6:7. Regarding the particular choice of vocabulary in 1 Chronicles 28:12 (ברוח), Knoppers opts for the understanding "Spirit." Through divine inspiration, David has insight in the organization of the temple compound, its various parts (courts, surrounding chambers, treasuries). Knoppers's interpretation seems correct also for the following reason: In Chronicles, the motif of the "spirit of God (YHWH)" appears several times. Interestingly, in two other texts רוח is used in the absolute sense, as in the present text, and means "spirit of God". ${ }^{18}$

There might be an influence by the book of Ezekiel, in which the expression in absolute use plays an important role (see Ezek 1; 37). ${ }^{19}$

15 See also Knoppers, 1 Chronicles 10-29, 931; Sara Japhet, 1 Chronik, HThKAT (Freiburg: Herder, 2002), 435 ("was ihm durch den Geist in den Sinn gekommen war").

16 See also Edward L. Curtis and Albert A. Madsen, Chronicles, ICC (Edinburgh: T\&T Clark, 1910), 298; Sara Japhet, I and II Chronicles, OTL (Louisville: Westminster John Knox, 1993), 481; Ralph W. Klein, 1 Chronicles: A Commentary, Hermeneia (Minneapolis: Fortress, 2006), 525.

17 Cf. Knoppers, 1 Chronicles 10-29, 931.

18 According to 1 Chron 12:19, "the Spirit" came upon Amasai, the chief of the thirty, and Amasai found the right words to convince David about the honorable intentions of the men who joined David in Ziklag. According to 2 Chron 18:20, in the assembly of YHWH it is the spirit (הרוח) who knows the means how to deceive King Abiah.

19 The movement of the wheels and the creatures besides them is coordinated by the "spirit" (רוח). See Walter Zimmerli, Ezekiel 1: A Commentary on the Book of the Prophet Ezekiel, Chapters 1-24, Hermeneia (Philadelphia: Fortress, 1979), 130. Concerning Ezek 37, see Zimmerli, Ezekiel 1, Chapters 1-24, 262. 


\subsubsection{Chronicles 28:18}

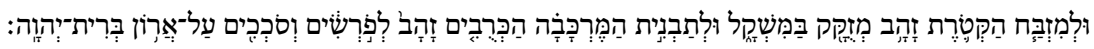
(and David gave him the weight of the gold) for the altar of incense of refined gold and for the model (tabnit) of the chariot, that is the cherubim, that spread out their wings, and covered the ark of the covenant of YHWH.

As for its third occurrence, tabnit appears as part of the compound noun "model of the chariot." David indicates the weight of the gold for the tabnit of the chariot. In this context, one should not translate tabnit with "plan", but rather with "model" or "construction." 20 David indicates the weight of the gold used for (ל) the altar of incense and for (ל) the "model of the chariot." Certain commentators ignore the preposition "for" (ל) and erroneously translate "(and David gave him) the plan of the chariot." 21 The chariot is equated with the cherubim-throne ("the chariot, that is the cherubim"). Probably, the author was influenced by Ezekiel 1 , where a similar idea is expressed. The cherubim constitute a vehicle having wheels. However, only in 1 Chronicles 28:18 the designation merkābâ for YHWH's "cherubim-chariot" appears; it is, besides Ben Sira 49:8, ${ }^{22}$ the only occurrence of this term in the Hebrew Bible, which later on in Jewish mystic movements became so important. Yet, concerning the wording, the question arises of why the author formulates in this indirect way: "for the model of chariot" instead of "for the chariot." Would he like to say that the "chariot" in the Holy of Holies is not the real throne of YHWH but only a model? Such a differentiation between "prototype" and "model" might have been suggestive to the author in light of the chariot-concept of Ezekiel 1. Here, the chariot forms a moving and enormous cloud touching the firmament above (see in particular Ezek 1:15-21). Therefore, according to the author of 1 Chronicles 28:18, the chariot in the Holy of Holies can be nothing more than a replication of the real, unseizable and uncapturable chariot of YHWH.

\subsubsection{Chronicles 28:19}

Verse 28:19, where the tabnit appears for the fourth time, has a textual difficulty and is, in general, challenging to understand. The Massoretic Text (MT) reads as follows:

20 Expressing this understanding, Japhet, 1 Chronik, 435.

21 See Klein, 1 Chronicles: A Commentary, 515; Japhet, I and II Chronicles, 481. See, however, Japhet, 1 Chronik, 435 (“und für das Modell des Wagens der Cherubim aus Gold”)!

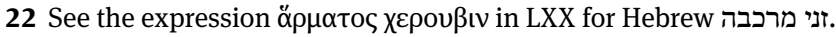




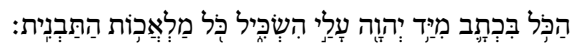

In all this by a writing from the hand of YHWH upon me he (YHWH) gave (me) insight

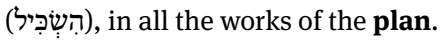

While MT reads עֵָׁלי “on me” or "to me”, the Septuagint, which deviates in many points from MT, reflects עָלָיו “on him”.

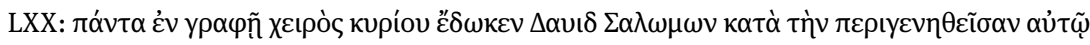

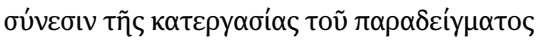

David gave all to Solomon in the Lord's handwriting, according to the knowledge given him of the work of the pattern.

If we adopt the reading of MT, verse 19 would include a direct speech by David referring back to verses 11-18. A difficulty of this understanding lies in the fact that the direct speech is not introduced. For this reason, some modern translations insert "and David said", although such facilitating plus is not attested in any textual witness. However, this striking feature, the change to the direct speech, may be explained as a stylistic particularity of the Chronicler. The same sudden shift from the $3^{\text {rd }}$ person to the $1^{\text {st }}$ person occurs also in 1 Chronicles 23:5. ${ }^{23}$

Many commentators read עָָׁלָי "on him" instead me," on the basis

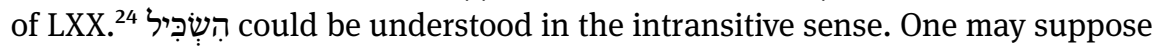
a scribal mistake in MT, namely a haplography of the two similar letters yod and waw. This reconstructed alternative text would read as follows:

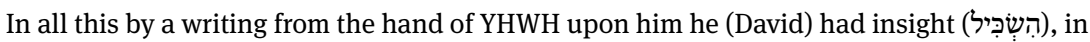
all the works of the plan.

Despite the uncertainty in the phraseology, the intention of this verse seems clear: David is inspired by a document written by God. It is through this document, that David has gained insight in all details of the temple architecture.

23 According to William Johnstone, 1 Chronicles 1 - 2 Chronicles 9. Israel's Place among the Nations, JSOTSup 253 (Sheffield: Sheffield Academic, 1997), 282, the author chose the "curious interjection in the first person ... in order to emphasize the surpassing authority of the divine revelation of the Temple and its cult to David." Knoppers, 1 Chronicles 10-29, 923 also follows MT. 24 See for instance, Wilhelm Rudolph, Chronikbücher, HAT 21 (Tübingen: Mohr Siebeck, 1955), 188; Japhet, I and II Chronicles, 482. 


\subsubsection{Originality of the Literary Composition in 1 Chronicles 28}

The specifications of the plan of the temple described in chapter 28 reveal that the author was strongly influenced by the Priestly tabernacle account and Ezekiel:

- The conception of the tabnit as written document, which originated in a plan written by God (1 Chron 28:11, 12, 19), is absent from the temple construction report in 1 Kings 6-7. Here, the Chronicler combines motifs found in the tabernacle account of P and in Ezekiel (in Ezek 43:11, Ezekiel is ordered to write down the vision of the temple).

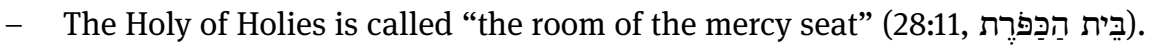
This peculiar designation is certainly influenced by the tabernacle account,

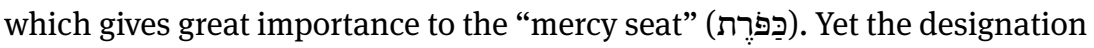
"room of the mercy seat" is absent in P.

- The depiction of the Cherubim as a chariot (28:18): As shown above, this motif is certainly influenced by the wheeled object described in Ezekiel 1 and 10. At the same time, the protecting function of the Cherubim as it appears in the tabernacle account is mentioned. ${ }^{25}$

However, the reader is also confronted with certain peculiar motifs which do not appear in the mentioned traditions but constitute novelties:

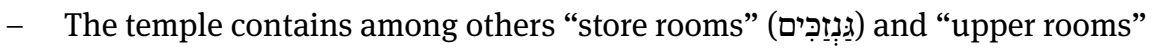
(עִלְלית) (cf. v. 11). Whereas the former expression is a hapax but is related to

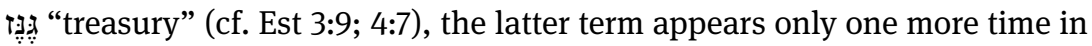
the Hebrew Bible (in 2 Chron 3:9). Mentioned are furthermore "inner rooms"

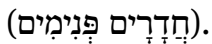

- As for the construction material, besides gold, which is the dominant metal, silver is mentioned too. The plan includes silver lampstands, silver tables, and silver bowls (cf. vv. 15-17). Strikingly, none of these items appears in the temple construction report in 1 Kings $6-8$, in the tabernacle account and in Ezekiel 40-48.

Summarizing this section, we state that in his development of the intriguing tabnit theme, the author of 1 Chronicles 28 borrows elements from different cult traditions, in particular from $\mathrm{P}$ and Ezekiel. He furthermore introduces certain items unknown in other biblical traditions apparently in order to provide a legitimation for novelties stemming from the Second Temple era.

25 Note, however, that the motif of the protecting function of the Cherubim is also found in 1 Kgs 8:7. 


\subsection{David takes the initiative for the generous donation in favor of the projected Temple (1 Chron 29)}

A further remarkable activity of King David related to the building of the temple is as follows: 1 Chronicles 29 reports how David takes the initiative for a generous donation in favor of the projected Temple (vv. 2-5). After having offered enormous donations himself, David summons the leadership of Israel (i. e. a large assembly including the leaders and the representatives of Israel's tribes and army) to contribute to the building project in equally substantial manner. As in the previous chapter, David's action recalls that of Moses in the Priestly tabernacle account, who gave the order to donate for the building of the tabernacle in the wilderness. In contrast to Moses, however, David, by offering generous donations himself, serves as a model for the assembled authorities. Another difference of Chronicles in comparison with the tabernacle account is the indication of precise quantities: these quantities are enormous.

Moreover, David addresses a prayer to YHWH in which he puts the donation in a theological perspective. In his point of view, all the vast riches he and the people donate to YHWH belong, in reality, to the deity (vv. 14, 16). At the end of the prayer, he furthermore petitions for the realization of the promised construction of the Temple (v. 19).

Looking on the chapters 1 Chronicles 28-29 as a whole, one becomes aware of how strongly it deviates from its primary Vorlage in Samuel-Kings. ${ }^{26}$ Together with the following chapter 29 it forms one unit culminating in Solomon's enthronement (1 Chron 29:23-25). While David's speech parallels David's speeches in 1 Kings 1-2 (in particular the farewell address to Solomon in 1 Kings 2:1-9), the two pericopes differ entirely with respect to their content. Whereas the latter, in its present form, may be characterized as "a fairly sordid story of power politics thinly disguised as a morality tale," 27 the former deals uniquely with important matters of the projected sanctuary: David entrusts the plan of the temple to Solomon, and he encourages the people to donate for it. The two versions of David's testament could not be more dissimilar!

26 See Japhet, I and II Chronicles, 483.

27 Cf. Iain W. Provan, 1 and 2 Kings, NIBCOT (Peabody, Mass.: Hendrickson, 1995), 40. 


\subsection{Appointment and diversification of the Levites by David (1 Chron 23-27)}

A third activity of David related to the cult foundation is the appointment of Levites and priests in 1 Chronicles 23-27. These five chapters give an overview of the inner organization of Levites in divisions. The Levites act as priests, as singers and as gatekeepers. Later on, these prescriptions by David are referred to as follows: The Levites are told to act and perform their duties "as prescribed in the writings of King David (בכתב דויד) of Israel and in the document of his son Solomon (שככבת)" (2 C) (שלמה)" (2 Chron 35:4). The author is aware that these detailed descriptions in chapters 23-27 are not found in the Torah given by Moses. Therefore, he refers to them as separate, complementing "writings". This reference to a distinct written document should probably be seen in close connection with the written plan, the tabnit, David received from YHWH and handed over to Solomon. ${ }^{28}$

The chapters 1 Chronicles 23-27 express the Chronicler's particular interest for the development of the cultic institutions, and the organization of the Temple personnel - a theme which is closely related to that of the planning of the sanctuary. ${ }^{29}$ The description in 1 Chronicles $23-27$ results in a highly complicated differentiation of groups and functions in the cultic community of Jerusalem. ${ }^{30}$ Knoppers concludes from his analysis that the responsibilities of the Levites and the priests are complementary and balanced: "Both the priests and the Levites are essential to the success of the Temple cultus. (...) (T)he summary of Levitical

28 See Steins, "Chronistisches Geschichtsbild und 'levitische Predigt'," 169 and see further below $\S 3$.

29 This interpretation was refuted by M. Noth on literary-critical grounds and with regard to the Chronicler's global plan. According to him, an author having the aim to validate the Levitical claims would not have referred to instructions edited by David. See Noth, The Chronicler's History, 100 (for the literary-critical argument, cf. 33). See also Adam C. Welch, The Work of the Chronicler: Its Purpose and Its Date (London: Oxford University Press, 1939); Thomas Willi, Die Chronik als Auslegung. Untersuchungen zur literarischen Gestaltung der historischen Überlieferung Israels, FRLANT 106 (Göttingen: Vandenhoeck \& Ruprecht, 1972), 194-204. The literary classification of 1 Chron 23-27 is disputed, but recent scholarship considers these chapters to be an integral part of the Chronicler's work. See John W. Wright, “The Legacy of David in Chronicles: The Narrative Function of 1 Chronicles 23-27,” JBL 110 (1991): 229-42; Japhet, I and II Chronicles, 406-11; Knoppers, 1 Chronicles 10-29, 788-98.

30 For a helpful overview on these chapters, see Louis C. Jonker, "David's Officials According to the Chronicler (1 Chronicles 23-27): A Reflection of Second Temple Self-Categorization?," in Historiography and Identity (Re)formulation in Second Temple Historiographical Literature, ed. Louis C. Jonker, LHBOTS 534 (London: T\&T Clark, 2010), 65-91; Louis C. Jonker, Defining All-Israel in Chronicles. Multi-levelled Identity. Negotiation in Late Persian-Period Yehud, FAT 106 (Tübingen: Mohr Siebeck, 2016), 246-52. 
duties is evidence for the Chronicler's own distinctive stance, a via media between the positions of Deuteronomy, the Priestly source, and Ezekiel.”31

\section{David as a second Moses: The Chronicler's handling of the Pentateuchal cultic tradition}

In his report on the foundation and building of the First Temple, the Chronicler transforms his Vorlage, the books of Samuel and Kings, radically. He is highly influenced by the Priestly tradition, in particular by the tabernacle account, and also by Ezekiel (see above). This influence of $\mathrm{P}$ and late- (or post-) Priestly texts is also visible in the chapters of the building and inauguration of the temple in 2 Chronicles 3-7. However, as shown above, in some of these texts it becomes evident that Chronicles deviate from the tabernacle account and compete with the latter. In certain respects, the foundation of the Jerusalem temple surpasses that of the tabernacle: the tabnit David received is a written document and not only orally transmitted; in contrast to Moses, it is through his personal generous donation that David encourages the assembled Israelites to consecrate their riches to YHWH; also, the tabernacle ("tent of meeting"), constructed by Moses in the wilderness, and at time established at Gibeon (2 Chron 1:3; 1 Chron 21:29), is deposited in the much bigger temple of David and Solomon (2 Chron 5:5). We have also seen that the author integrates certain novelties of the second temple in his report. David's innovations are significant; he plays a role similar to Moses. Yet, David's instructions are called “writing" (כתב), "ordinance" (מצוה), and "law" rather than "Torah". ${ }^{32}$ Therefore, at first sight, one might think that the author attributed to the ancient prescriptions preserved in the Torah a higher status than to David's writings. As Noth puts it: “(...) in the cultic sphere the age of an ordinance is always a valid legitimation: the older carries greater weight than the more recent." ${ }^{33}$ Noth concluded that "the more recent arrangements of David could not make any headway against the older pronouncements of Moses.” ${ }^{34}$ He was critical of the view that the Chronicler intended to justify certain novelties in the cult. Pursuing such a goal, the reformer of the cult "would have had

31 Gary N. Knoppers, "Hierodules, Priests, or Janitors? The Levites in Chronicles and the History of the Israelite Priesthood,” JBL 118/1 (1999): 49-72, here 71.

32 "Writings" and "ordonances" attributed to David are mentioned in 1 Chron 28:19 (משומ) (כתב); 2 Chron 8:14 (מצוה ,משפט); 29:25 (מצוה) (מצוה); $35: 15$ (כתב).

33 Noth, The Chronicler's History, 100.

34 Noth, The Chronicler's History, 100. 
to expand the tradition of Moses to conform it to his purpose." ${ }^{35}$ However, such reasoning does not consider the possibility that at the Chronicler's time the Torah was already a closed corpus. As mentioned above, the redaction of 1-2 Chronicles probably presupposes the achievement of the Pentateuch and the wide recognition of its authoritative status. Therefore, basically, the only way to bring in innovations into the Israelite cultic system was to invent another "collection" of prescriptions and to assign the latter to an authority equal to Moses. ${ }^{36}$ The author of Chronicles has found this authority in David whom he conceived as recipient and transmitter of the tabnit of the temple and further cultic ordinances. There is indeed an indication that the author is keen to see David and Moses on equal footing. As mentioned above in the introduction, David is given the same extraordinary attribute "man of God" (איש האלהים) as Moses. ${ }^{37}$ David receives this title in his function as cult founder, in striking analogy to Moses, the founder of the cult (cf. 2 Chron 8:14 with 2 Chron 30:16). ${ }^{38}$

"Following the prescription of his father David, he set up the divisions of the priests for their duties, and the Levites for their watches, to praise and to serve alongside the priests, according to each day's requirement, and the gatekeepers in their watches, gate by gate, for such was the commandment of David, the man of God (כמצות דויד איש האלהים)" (2 Chron 8:14; JPS Tanakh).

"They took their stations, as was their rule according to the Teaching of Moses, man of God (כתורת משה איש האלהים). The priests dashed the blood which they received from the Levites.” (2 Chron 30:16; JPS Tanakh)

Furthermore, both, Moses and David, are called "servant of God / YHWH" and "my servant" respectively. ${ }^{39}$

The emphasis put on the equality between the two authority figures should not be interpreted in the sense that David is just Moses' succeeder and imitator.

35 Noth, The Chronicler's History, 100.

36 Another way was to declare certain novelties as Mosaic Torah. For an example see Willi, "Thora in den biblischen Chronikbüchern," 149-50. In 2 Chron 30:16 (text displayd below) the Torah seems expanded in favour of the Levites.

37 Used for Moses: 1 Chron 23:14; 2 Chron 30:16; applied to David: 2 Chron 8:14.

38 See William M. Schniedewind, The Word of God in Transition: From Prophet to Exegete in the Second Temple Period. JSOTSup 197 (Sheffield: Sheffield Academic Press, 1995), 50-51.

39 Moses: 1 Chron 6:34; 2 Chron 1:3; 24:6, 9; David: 1 Chron 17:4, 7; 2 Chron 6:16. To be sure, none of the two expressions is used exclusively for Moses and David: איש האלהים is also applied to Shemaiah (2 Chron 11:2); in his prayer Solomon designates himself as "your servant" (2 Chron 6:19). 
Rather, high status and esteem accorded to David reveal that he is conceived as an innovator of Israel's cult, precisely like Mose was at his time. ${ }^{40}$

\section{The Chronicler's ideological agenda}

The above investigation has shown that the Chronicler's presentation of king David's preparation of the temple building and establishment of cult challenges both the tradition of 1-2 Kings and the Mosaic tabernacle account. What are his main motivations to do so? The answer I propose in conclusion to this question goes in three different directions:

(1) First, the Chronicler's motivation is theological-exegetical: In 1 Kings 6-8, the Chronicler's Vorlage, a divine authorization of the chosen temple architecture is absent. Compared with the Priestly tabernacle account in Exodus 25-29; 35-40 which relates that Moses was shown the plan of the tabernacle by YHWH, Solomon's building project in the book of Kings appears theologically deficient. Therefore, the author of Chronicles intended to correct his Vorlage, the Book of Kings, at this point. Like with the building of the tabernacle, the construction of the Solomonic Temple should be based on a tabnit (see 1 Chron 28). Doing so, the Chronicler provides a better legitimation for the Solomonic temple than that given in Samuel-Kings. He establishes "a long continuity in cultic affairs from the time of Moses to the time of the monarchy" with its emblematic figure David. ${ }^{41}$

Furthermore, the comparison of the two sections 1 Chron 28-29 and 1 Kings 1-2 presenting both a testament by David brings nicely into relief the Chronicler's intention to associate king David primarily with the foundation of the temple in Jerusalem and its cult rather than with the concern of his succession and the maintenance of his dynasty. In general, as argued above in the introduction $(\S 1)$, the great importance assigned to David and his dynasty by the author is primarily due to the high value accorded to to the Jerusalemite temple and its foundation. According to the pointed statement of Beentjes, "David's dynasty only matters as long and in as far as it guarantees optimal conditions for the construction of the temple and the preservation of the cultic institutions." 42

\footnotetext{
40 Similarly, von Rad, Das Geschichtsbild des chronistischen Werkes, 130; Jaeyoung Jeon, "The Priestly Tent of Meeting in Chronicles: Pro-Priestly or Anti-Priestly?” JHS 18/7 (2018), 1-15, here 11. 41 Knoppers, 1 Chronicles 10-29, 941.

42 Beentjes (Tradition and Transformation, 103), “David's dynasty only matters as long and in as far as it guarantees optimal conditions for the construction of the temple and the preservation of the cultic institutions."
} 
(2) The Chronicler has a cult-theological interest. He aims to provide a legitimate basis for certain novelties of the Second Temple architecture which are unknown in both tabernacle account and 1 Kings 6-8. It would be particularly interesting to know more about the function of the "treasure rooms" and "upper rooms" in the temple at the Chronicler's time (according to 2 Chron 3:8-9 the "upper rooms" were located close to the Holy of Holies and overlaid with gold). Furthermore, 1-2 Chronicles strengthen the position of the Levites and assigns them new tasks. The Chronicler's aim is to put the innovations on a par with the elements stemming from the ancient traditions and thus to legitimize them. By this, the Chronicler brings the continuous tradition into his own time: the tradition runs from Moses through David-Solomon to the Second Temple community.

(3) The Chronicler has a cult-political interest: The establishment of a continuous tradition was all the more important because, according to the Chronicler, the Priestly tabernacle account, a composition stemming from the Persian era, could not serve this aim - at least not in an appropriate manner. Regarding the P's tabernacle account, a problematic aspect for the author of Chronicles probably was the location in the wilderness, far away from Jerusalem, and the absence of any explicit link to the temple in Jerusalem. Because of these particularities, the tabernacle account may well have contributed to the decentralization of the cult in the Persian era and may have served as a model for different sanctuaries, even though this was probably not the intention of the tabernacle account. ${ }^{43}$ Today, it is known that a YHWH temple existed in Elephantine in Egypt in Persian times

43 There are important indications that the tabernacle account aims towards the Jerusalem temple as it is described in the report of the building of the Solomon's temple (1 Kgs 6-8). Common points and parallels between the two accounts are as follows: (1) The general structure, orientation and measurements of the tabernacle correspond largely to those of the Solomonic temple. Both sanctuaries are rectangular and have an east-west orientation. Both have a holy of holies (inner sanctum), holy place (outer sanctum), and a courtyard. As for the measurements of the tabernacle (footprint: $30 \times 10$ cubits), they correspond to those of the Solomonic temple (footprint: $60 \times 20$ cubits), covering precisely half of the area of the temple of Jerusalem. (2) The tabernacle account describes important items of furniture appearing in the report of the construction of Solomon's temple (cherubim, wooden lining, ark, table, lamp[s]). (3) The ornamentation with cherubim on the walls and with curtains respectively, is similar. (4) Both accounts describe similar elaborate architectures reflecting a gradation of sanctity through the subdivision of the sanctuary area, and through the attribution of different building materials to the three areas (gold and precious wood for the furniture of the holy of holies and of the outer sanctum; bronze for the articles of the court). See, among others, Menahem Haran, Temples and Temple Service in Ancient Israel (Oxford: Oxford University Press, 1978), 189-94; Suzanne Boorer, The Vision of the Priestly Narrative: Its Genre and Hermeneutics of Time, Ancient Israel and Its Literature 27 (Atlanta: SBL, 2016), 306-10; Jürg Hutzli, "Priestly(-like) Texts in Samuel and Kings," in Writing, Rewriting, and Overwriting in the Books of Deuteronomy and the Former Prophets. Essays in Honour 
and another one on Mount Gerizim close to Shechem. The numerous dedication inscriptions found in the excavations on Mount Gerizim, particularly contain several motifs that are reminiscent of the Priestly tabernacle account and other Priestly texts. ${ }^{44}$ The author of Chronicles, facing this for him problematic reception history of the tabernacle account, wanted to reaffirm YHWH's exclusive election of the Jerusalem temple and its cultic community for all times. ${ }^{45}$ The means to emphasize Jerusalem's election was the insertion of the motif of the divine inspiration of the building plan for the Solomonic temple and the depiction of king David as transmitter of this plan and promulgator of cultic laws. By this, the continuity between Moses' tabernacle and the Jerusalem temple was assured and specified: The tabernacle account, as a foundation myth of Israel's cult, should be understood in a strict exclusive way: it aimed only towards the temple of Jerusalem but not to any other Yahwistic sanctuaries as well.

of Cynthia Edenburg, ed. Ido Koch, Thomas Römer, and Omer Sergi, BETL 304 (Leuven: Peeters, 2019), 224-25.

44 For the editio princeps, see Yitzhak Magen, Haggai Misgav, and Levana Tsfania, Mount Gerizim Excavations, I: The Aramaic, Hebrew and Samaritan Inscriptions, JSP 2 (Jerusalem: Staff Officer of Archaeology, 2004). Concerning the dating of the inscriptions: Jan Dušek, Aramaic and Hebrew Inscriptions from Mt. Gerizim and Samaria between Antiochus III and Antiochus IV Epiphanes, CHANE 54 (Leiden: Brill, 2012), 6-62; Anne Katrine de Hemmer Gudme, Before the God in This Place for Good Remembrance: A Comparative Analysis of the Aramaic Votive Inscriptions from Mount Gerizim, BZAW 441 (Berlin: de Gruyter, 2013), 78-84; Reinhard Pummer, "Samaritan Studies - Recent Research Results,” in The Bible, Qumran, and the Samaritans, ed. Magnar Kartveit and Gary N. Knoppers, Studia Samaritana 10/STJ 104 (Berlin: de Gruyter, 2016), 66-7. 45 Similarly, Noth, The Chronicler's History, 100-101. 